\title{
Modelling manpower and equipment productivity in tall residential building projects in developing countries
}

\author{
M K Parthasarathy, R Murugasan, Ramya Vasan
}

This study is aimed at developing productivity models based on the combined usage of manpower and equipment resources in construction for tall residential building projects in India. Data was collected from 52 tall residential building projects in different locations for a consecutive period of 18 months for the five basic activities of construction: concreting, reinforcement, formwork, blockwork and plastering. Multiple linear regression analysis was used to develop 15 models - three models each in different conditions for the five basic construction activities for manpower and equipment productivity, and were validated with independent field data. In addition, the factors affecting productivity of manpower and equipment were analysed through a qualitative study by collecting and examining responses to questionnaires from 96 respondents involved in the 52 projects. The study found that improper planning of work was the most important factor affecting the productivity in tall residential building projects. The models developed in the study, and the analysis of factors affecting productivity will be useful to cost engineers and project managers to estimate the productivity of resources in tall residential building projects in India and other developing countries where similar conditions prevail.

\section{INTRODUCTION}

The construction industry plays a vital role in the development of India, one of the steadiest and fastest growing countries in the world (Economic Report of the President 2016). Being the second largest contributor to Gross Domestic Product (GDP) after agriculture, construction employs a workforce of nearly 35 million in addition to a variety of equipment. In fact, its market size is worth about $\$ 126$ billion, according to the Department of Industrial Policy and Promotion, Government of India in 2016. A Financial Express report predicted that more than $40 \%$ of the population would be residing in urban areas by 2030, and suggested that approximately 400 million people would be migrating to cities in a period of 15 years from 2016 to 2030 (Gulati 2016). Consequently, urbanisation and increased demand for space in developing countries like India have led to large-scale construction of tall residential buildings, and impacted the basic activities of construction like concreting, reinforcement, formwork, blockwork and plastering. In developing countries these basic activities are executed with a combination of manpower and equipment resources, due to the easy availability of manpower and the high cost of equipment. Such a combined approach to construction requires a scientific approach to the planning and execution of projects. This problem can be addressed primarily by tall building residential projects, a solution of great potential for the development of cities and urban spaces worldwide (Elbakheit 2012).

As in other developing countries, India is faced with the challenge of affordable and comfortable tall building construction projects to meet the high demand for space in urban localities. Studies on productivity in construction projects in the Indian context by Attar et al (2014), Patil (2015), Santosh and Apte (2014), and Shashank et al (2014) highlighted the productivity measurement, as well as the methods. They also discussed the large quantum of manpower and equipment resources involved, but did not suggest any models which could be used for tall building projects. On the other hand, the models developed by Antunes and Gonzalez (2015), Gundecha (2012), Jrade et al (2012), Wang (2005) and others in other countries for construction productivity mainly focused on work methods,
JOURNAL OF THE SOUTH AFRICAN INSTITUTION OF CIVIL ENGINEERING ISSN 1021-2019 Vol 60 No 2, June 2018, Pages 23-33, Paper 1547

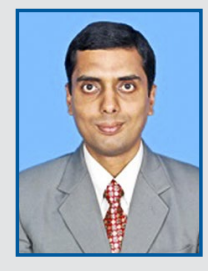

DR M K PARTHASARATHY works as Senior Deputy General Manager in the Construction Division of Larsen \& Toubro Limited, an Indian multinational engineering company. He is currently Head, Project Controls, for the construction of a $220 \mathrm{~m}$ high-rise building comprising a Hotel Tower (350 keys) and Residential Tower (150 high-end apartments) in Colombo, Sri Lanka; the project has a contract value of USD 354 million. He is a civil engineer by profession and has more than 25 years' experience in construction and project management. His interests include management information systems, procurement and execution of major construction engineering projects. He also conducts in-house training programmes in the aforementioned areas for the knowledge enhancement of company employees.

Contact details:

Department of Civil Engineering

Anna University

Chennai 600025, India

T: +91 4422597377 , E: balaji_parth@hotmail.com

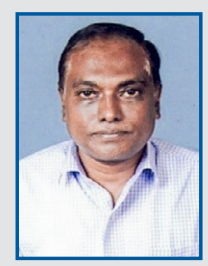

DR R MURUGASAN works as Associate Professor in the Institute of Remote Sensing, Department of Civil Engineering, College of Engineering Guindy, Anna University College of Engineering, one of the premier institutions in India, established in 1794. His teaching interests include highway engineering, construction management and remote sensing. He is a civil engineer by profession and has more than 30 years' experience in the aforementioned fields. He has done more than 16000 hours of teaching to under- and post-graduates in engineering, and has guided $11 \mathrm{PhD}$ research scholars. He is also a consultant for many private and government agencies in the field of coastal zone management, using satellite remote sensing.

Contact details:

Department of Civil Engineering

Anna University

Chennai 600025, India

T: +91 442235 8178, E: murugasanr@rediffmail.com

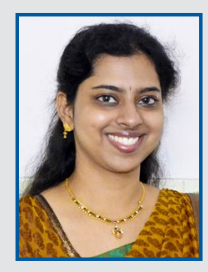

RAMYA VASAN works as Manager, Procurement in the Construction Division of Larsen \& Toubro Limited, an Indian multinational engineering company. She specialises in the procurement of civil and architectural items. She has good knowledge of construction management, and also of management information systems related to construction management. She is also an expert in costing and the review of costing in construction projects. A civil engineer by profession, she has accumulated 11 years' experience, working for the same company.

Contact details:

Larsen \& Toubro Limited

Construction Division

Chennai 600089, India

T: +91 4422597378 , E: ramya.vasa@gmail.com

Keywords: construction, residential buildings, tall buildings, productivity, modelling 
the factors affecting the productivity, productive time of trade, etc. A careful study of these models indicated that they were area-specific and could not be used as prediction models for construction in developing countries, the major reason being that construction in developing countries involves a combination of equipment usage and manual labour, unlike in developed countries where the activities are predominantly mechanised.

This study is therefore aimed at developing scientific models to estimate the productivity of manpower and equipment in tall residential building projects with a height of $30 \mathrm{~m}$ or more in India, bearing in mind the seasonal variances in monsoon and non-monsoon periods, as well as factors affecting the productivity of manpower and equipment.

\section{LITERATURE REVIEW}

A few studies on the modelling of manpower and equipment productivity for tall residential building projects which have direct relevance to the current study are discussed in this section.

Zayed and Halpin (2005) estimated the productivity and cost of pile construction using the regression technique in the United States. They designed 52 regression models to assess piling process productivity and cycle time. They validated the models to assure their appropriateness in the assessment process by developing several sets of charts that represented productivity, cycle times and cost. They concluded that productivity was directly related to the achievement of cycle time using piling equipment. They further observed that variation happened if the cycle time of piles on one piece of equipment was not achieved.

Al-Zwainy et al (2013) used the Multivariable Linear Regression Technique for modelling productivity of construction, with a focus on marble finishing works in Iraq. They used parameters like age, experience, number of assisting workmen, height of the floor, size of the marble tiles, security conditions, health status of the work team, weather conditions, site condition and availability of construction materials as independent variables. They developed a model based on 100 sets of data collected in Iraq from different types of construction, such as residential, commercial and educational projects. They concluded that the size of finished marble blocks had the most significant effect on the productivity of marble finishing works for floors, while the other input variables had a moderate impact on the productivity.

Gupta and Kansal (2014) examined the factors affecting labour productivity in construction sites in India. They invited professionals such as project managers, project engineers, site engineers, architects, assistance project managers, assistance project engineers and others who worked on the project, from management to execution level, to participate in a questionnaire survey. The questionnaire had four primary groups of factors, i.e. management, technological, human/labour and external. They found that ten factors of clarification in technical specifications (labour supervision, method of construction, delay in payment, labour fatigue, lack of construction managers' leadership, extent of variations/change in order during execution, late arrival, early quitting and frequent unscheduled breaks, labour skill, and availability of experienced labour) affected construction labour productivity in the Chambal Region.

An examination of the available literature indicated that very few studies had developed models for estimating productivity on tall building projects. It further showed that research was not carried out in the context of a combination of both manpower and equipment resources. Finally, it was observed that the research outcomes were based on area-specific studies and had no scope for application in tall residential building projects. Hence, this study explored the options of developing models for estimating productivity in tall residential building projects. In addition, it attempted to examine various factors influencing productivity when construction was carried out with a combination of manpower and equipment resources.

\section{OBJECTIVES OF THE STUDY}

The objectives of this research are:

- To develop prediction models for manpower and equipment productivity, using multiple linear regression for the main activities of tall residential building construction like concreting, reinforcement, formwork, blockwork and plastering, considering the resources as independent variables, and for conditions prevailing in developing countries.
- To validate the developed models by comparing theoretical and actual quantities of each item, so that the models can be used for planning and utilisation of resources in projects.

- To examine and classify the factors affecting productivity of manpower and equipment in tall residential building projects.

- To rank the factors affecting productivity in descending order of their intensity in terms of frequency indices.

\section{RESEARCH METHOD}

This is an empirical study of tall residential building projects in India. First, it identified the tall buildings located in different parts of India and prepared a database for the selection of projects and the collection of data. It regularly collected data pertaining to the five basic activities over a period of 18 months. Multiple linear regression analysis was used to develop manpower and equipment productivity models. Independent field data was used to validate the models developed in this study. Thereafter questionnaires were used to collect information regarding the factors affecting tall building projects from 96 respondents involved in 52 projects.

\section{DATA BASE DEVELOPMENT}

\section{Project selection criteria}

A set of criteria was employed to select the 52 tall building projects:

- The final height of the building should be more than or equal to $30 \mathrm{~m}$.

- The building should be a framed Reinforced Cement Concrete (RCC) structure with column-slab design and it should not involve any composite construction.

- All the five selected basic activities should be on-going at various height levels in the project.

- The floor height in each level should be $3 \mathrm{~m}-4 \mathrm{~m}$, which is the normal floor to floor height in India.

- The project sites should be distributed throughout the country.

Based on these criteria, 52 tall residential building construction projects were chosen for the study. This in turn determined the distribution of two sets of questionnaires to 130 persons involved in different trades among consultants, execution teams, planning personnel, etc. 
Table 1 Range of data used for model development and validation

\begin{tabular}{|c|c|c|c|c|c|}
\hline Description & Notation & Unit & Minimum & Maximum & Mean \\
\hline Height & $\mathrm{H}$ & Metre & 3 & 174 & 41 \\
\hline Concrete quantity & Conc & $\mathrm{m}^{3}$ & 276 & 9321 & 3367 \\
\hline Man-days & MD & man-days & 251 & 4575 & 1193 \\
\hline Tower crane hours 30\% & $\mathrm{TCH}$ & hours & 301 & 2570 & 692 \\
\hline Concrete pump hours & $\mathrm{CPH}$ & hours & 200 & 1148 & 354 \\
\hline Transit mixer hours & $\mathrm{TMH}$ & hours & 120 & 1415 & 417 \\
\hline Batching plant hours & $\mathrm{BPH}$ & hours & 50 & 857 & 241 \\
\hline Reinforcement quantity & Rft & MT & 1 & 1495 & 474 \\
\hline Man-days & MD & man-days & 211 & 28319 & 6617 \\
\hline Tower crane hours 30\% & $\mathrm{TCH}$ & hours & 251 & 671 & 352 \\
\hline Bar cutting hours & $\mathrm{BCH}$ & hours & 80 & 6694 & 496 \\
\hline Bar bending hours & $\mathrm{BBH}$ & hours & 115 & 7260 & 537 \\
\hline Formwork quantity & FW & $\mathrm{m}^{2}$ & 1 & 40491 & 14749 \\
\hline Man-days & MD & man-days & 122 & 39127 & 9972 \\
\hline Tower crane hours 30\% & $\mathrm{TCH}$ & hours & 215 & 2028 & 624 \\
\hline Hoist hours & $\mathrm{HH}$ & hours & 140 & 4569 & 1264 \\
\hline Blockwork quantity & BW & $\mathrm{m}^{2}$ & 34 & 5141 & 2605 \\
\hline Man-days & $\mathrm{MH}$ & man-days & 315 & 4880 & 1538 \\
\hline Tower crane hours 10\% & $\mathrm{TCH}$ & hours & 86 & 1088 & 402 \\
\hline Hoist hours & $\mathrm{HH}$ & hours & 141 & 2506 & 951 \\
\hline Plastering quantity & $\mathbf{P}$ & $\mathrm{m}^{2}$ & 39 & 15104 & 7716 \\
\hline Man-days & MD & man-days & 168 & 14355 & 4405 \\
\hline Hoist hours & $\mathrm{HH}$ & hours & 149 & 7895 & 2667 \\
\hline
\end{tabular}

\section{Data collection}

Once the activities and projects had been selected, the manpower input and equipment usage for each activity were recorded on a monthly basis for every project. In the case of equipment like and $30 \%$ for formwork. Similarly, the distribution of time for all equipment was determined for this study. The distribution of percentages of equipment time to different activities was based on the experience of the project personnel and the allocation log sheets maintained by the plant and equipment (P\&E) departments in the 52 project sites.

The heights of the building, i.e. the point from where the work commenced at the start of the month to the point to where work had progressed by the end of the month, were recorded. The mean of these two heights was considered as the height at which the activity was carried out during the month.

The range of data collected from the 52 tall building construction projects is given in Table 1.

\section{Factor selection for factor analysis}

Twenty-one factors affecting the productivity of manpower and 20 factors affecting equipment productivity were identified for this study from various sources:

- Studies available from construction industry and other projects.

- The opinion of personnel involved in the construction of tall building projects, based on their experience.

- Empirical data on losses due to productivity from a multinational organisation in the area of study.

- The opinions of contract managers while estimating the costs of tall residential building projects.

tower cranes and hoists, which were shared for many activities in the given project, a percentage of time allocation was considered for different activities. For example, tower crane time was distributed as $35 \%$ for concrete, $35 \%$ for reinforcement
The list of factors considered for this study, with their classification in respective categories, is shown in Table 2(a). The critical literature review of the factors affecting

Table 2(a) Factors affecting manpower and equipment productivity

\begin{tabular}{|l|l|l|l|l|}
\hline Factor & Factor no & Affecting equipment productivity & Factor no & Affecting manpower productivity \\
\hline & EH1 & Lack of skilled operator & MH1 & Lack of skill \\
\hline Human factors & EH2 & Lack of support staff & Lack of motivation \\
\hline & EH3 & Lack of proper maintenance & Improper team formation \\
\hline & EP1 & Improper planning of work & MH4 & Lack of supervision \\
\hline EP2 & Non-availability of materials & MH5 & Threatening by management \\
\hline Planning factors & MH6 & Senior pressure/competition \\
\hline & EP3 & Interfacing of activities & MP1 & Improper planning of main works \\
\hline & & MP2 & Improper planning of support works \\
\hline
\end{tabular}




\begin{tabular}{|c|c|c|c|c|}
\hline \multirow{7}{*}{ System factors } & \multirow{2}{*}{ ES1 } & \multirow{2}{*}{ Improper access and egress } & MS1 & Improper access and egress \\
\hline & & & MS2 & Long lead \\
\hline & \multirow{2}{*}{ ES2 } & \multirow{2}{*}{ Excess travel/ lifting } & MS3 & Excess lift \\
\hline & & & MS4 & Lack of standard procedures \\
\hline & \multirow{3}{*}{ ES3 } & \multirow{3}{*}{ Non-payment of dues } & MS5 & Non-payment of dues/salary \\
\hline & & & MS6 & Improper house-keeping \\
\hline & & & MS7 & Not using advanced systems \\
\hline \multirow{4}{*}{ Environmental factors } & \multirow{2}{*}{ EE1 } & \multirow{2}{*}{ Extreme weather conditions } & ME1 & Extreme climatic conditions \\
\hline & & & ME2 & Lack of proper illumination \\
\hline & \multirow{2}{*}{ EE2 } & \multirow{2}{*}{ Lack of water/ hygiene } & ME3 & Accommodation, transport \\
\hline & & & ME4 & Lack of water, sanitation \\
\hline \multirow{9}{*}{ Resource/ equipment factors } & ER1 & Lack of support equipment & - & - \\
\hline & ER2 & Non-availability of fuel & - & - \\
\hline & ER3 & Non-availability of spares & - & - \\
\hline & ER4 & Lead time & - & - \\
\hline & ER5 & Delay in installing the equipment & - & - \\
\hline & ER6 & Two or more gangs sharing a piece of equipment & - & - \\
\hline & ER7 & Equipment breakdown & - & - \\
\hline & ER8 & Sub-standard spares, etc & - & - \\
\hline & ER9 & Use of high-end equipment where not required & - & - \\
\hline
\end{tabular}

Table 2(b) Summary of literature for factors affecting productivity

Author(s)

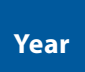

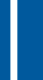

\section{Study method}

2009

Dai et al

Enhassi et al

Mistry and Bhatt

Chigara and Moyo

2014

(1)

Chigara and Moyo

5

Robles et al

6 Shashank et al

\section{Questionnaire survey}

and regression analysis

Questionnaire survey and regression analysis
Area of study

Number of factors

USA

83 engineering drawing management, direction and coordination, project management, training, craft worker qualification, superintendent competency, and foreman competency

Material shortage, lack of labour experience, lack of labour surveillance, misunderstandings between labour and superintendent, and drawings and specification alteration during execution

Delay in payments, skill of labour, clarity of technical specification, shortage of materials, and motivation of labour

Non-availability of materials, late payment of salaries and wages, suitability/adequacy of plant and equipment, supervisory incompetence, and lack of manpower skills

Shortage or late supply of materials, non-clarity of drawings and project documents, lack of clear and daily task

assignment, tools or equipment shortages, and poor level of skill and experience of labourers

India

Manpower group, managerial group, motivation group, material/equipment group, safety group, and quality group

Clarification in technical specifications, labour supervisions, method of construction, delay in payment, labour fatigue, lack of leadership from construction managers, extent of variations/change of order during executions, late arrival, early quitting and frequent unscheduled breaks, labour skills, and availability of experienced labour

Labour productivity of the formwork activity, and labour productivity of the rebar activity 


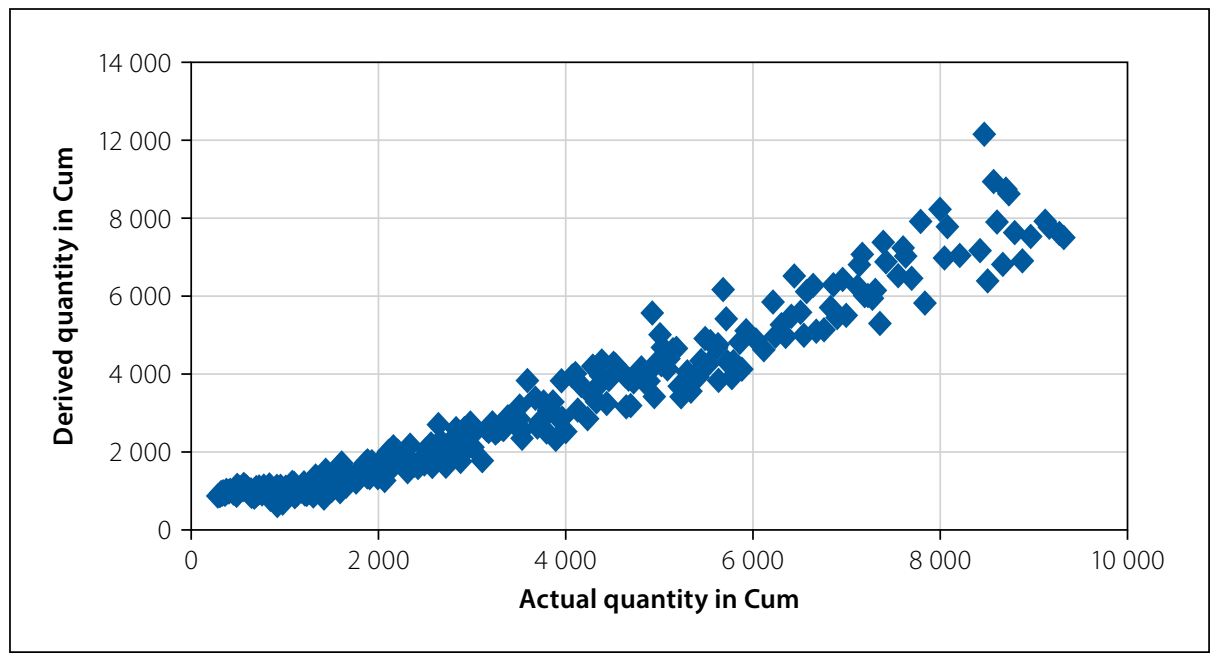

Figure 1 Comparison of actual and predicted quantities for concrete

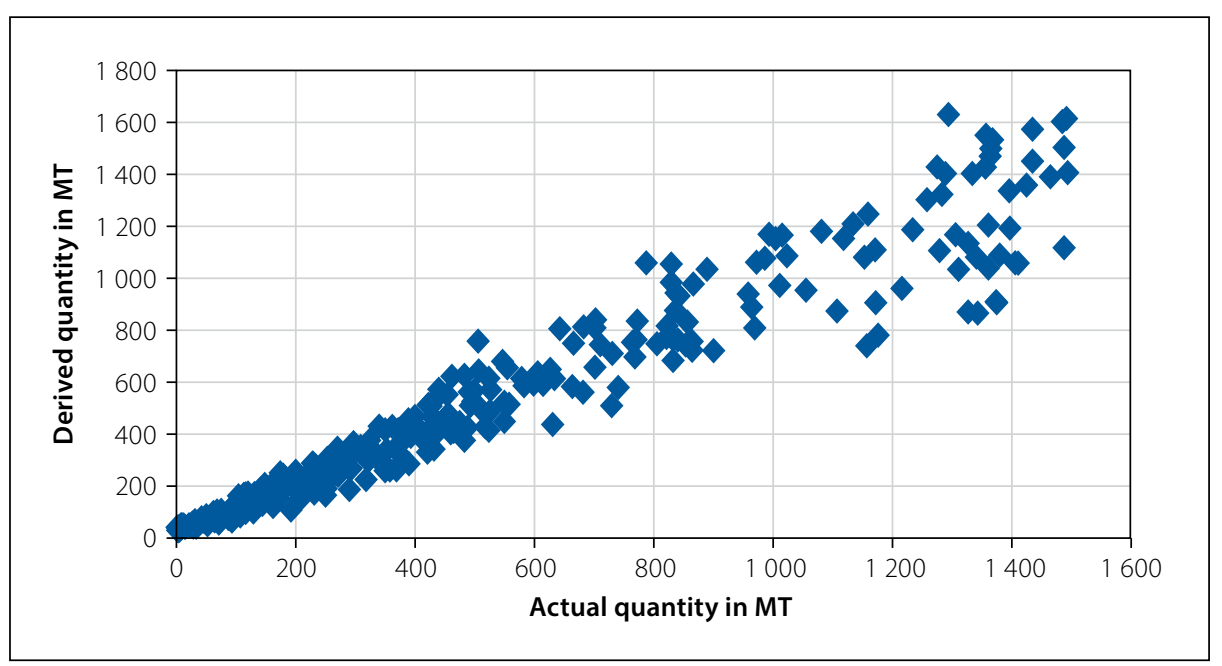

Figure 2 Comparison of actual and predicted quantities for reinforcement

manpower and equipment productivity is given in Table 2(b).

\section{QUANTITATIVE ANALYSIS AND DEVELOPMENT OF MODELS}

The data from the 52 projects was collected and sorted for each of the five basic construction activities. Data pertaining to every third month from the start date of data collection was separated as out-ofsample for the purpose of validation, and the remaining months' data was used as sample for the formulation of the models. Models were developed in this study for estimating productivity of the five activities: concrete, reinforcement, formwork, blockwork and plastering. Further, the effect of monsoon was also studied, and models were developed for each activity in monsoon and non-monsoon periods separately. According to the Indian Meteorological Department, India receives rain from two monsoons, namely the Southwest Monsoon from the end of May to the beginning of September every year, and the Northeast Monsoon from the beginning of October to the end of December. Four categories/areas of monsoon were considered, with reference to the onset of the two monsoon periods in India: A. Northern and western regions - June, July and August

B. Eastern region - July, August and September

C. Southeastern region - October and November

D. Southwestern region - May, June and July

The data was separated as sample for modelling and as out-of-sample for validation. Overall, the data separated for the purpose of validation was $30 \%$ of the total data set.

\section{Concrete quantity model}

In this model, concrete quantity was the dependent variable, whereas the parameters of height $(H)$, man-days $(M D)$, tower crane hours $(T C H)$, pump hours $(C P H)$, transit mixer hours $(T M H)$ and batching plant hours $(B P H)$ were independent variables.
The best model obtained using multiple linear regression analysis is:

$$
\begin{aligned}
\text { Conc }= & -448.751-1.249 H+0.402 \mathrm{MD} \\
& +0.902 \mathrm{TCH}+1.371 \mathrm{CPH} \\
& +2.155 \mathrm{TMH}+5.735 \mathrm{BPH}
\end{aligned}
$$$$
\left(\mathrm{R}^{2}=0.953 ; \mathrm{N}=624 ; \mathrm{SE}=528.58\right) \quad(\text { Model } 1)
$$

The plot between actual quantity (from out-of-sample data) and the derived quantity (sample data) for concrete validates the model, as shown in Figure 1. The alignment of plotted points along the line of equality indicates the robustness of the model.

The model for concrete quantity in the monsoon period is:

$$
\begin{aligned}
\text { Conc monsoon }= & -674.443-0.322 \mathrm{H} \\
& +0.328 \mathrm{MD}+1.127 \mathrm{TCH} \\
& +1.291 \mathrm{CPH}+2.804 \mathrm{TMH} \\
& +5.262 \mathrm{BPH}
\end{aligned}
$$

$\left(\mathrm{R}^{2}=0.957 ; \mathrm{N}=136 ; \mathrm{SE}=520.34\right)$

(Model 2)

The model for concrete quantity in the non-monsoon period is:

$$
\begin{aligned}
& \text { Conc non-monsoon }= \\
& \quad-266.949-2.229 H+0.358 \mathrm{MD} \\
& +0.809 \mathrm{TCH}+1.328 \mathrm{CPH} \\
& +2.181 \mathrm{TMH}+5.610 \mathrm{BPH}
\end{aligned}
$$$$
\left(\mathrm{R}^{2}=0.946 ; \mathrm{N}=486 ; \mathrm{SE}=569.22\right)
$$

(Model 3)

\section{Reinforcement quantity model}

In this model, reinforcement quantity was the dependent variable, whereas the parameters of height $(H)$, man-days $(M D)$, tower crane hours $(\mathrm{TCH})$, bar cutting hours $(B C H)$ and bar bending hours $(B B H)$ were independent variables.

The best model obtained using multiple linear regression analysis is:

$$
\begin{aligned}
\mathrm{Rft}= & -210.221-0.119 H+0.047 \mathrm{MD} \\
& +0.997 \mathrm{TCH}+0.438 B C H-0.370 \mathrm{BBH} \\
\left(\mathrm{R}^{2}=\right. & 0.932 ; \mathrm{N}=624 ; \mathrm{SE}=106.69) \quad(\text { Model } 4)
\end{aligned}
$$

The plot between actual quantity (from out-of-sample data) and the derived quantity (sample data) for reinforcement validates the model, as shown in Figure 2. The alignment of plotted points along the line of equality indicates the robustness of the model.

The model for reinforcement quantity in the monsoon period is:

$$
\begin{aligned}
\text { Rft monsoon }= & -303.834-0.120 \mathrm{H} \\
& +0.039 \mathrm{MD}+1.355 \mathrm{TCH} \\
& +0.430 \mathrm{BCH}-0.341 \mathrm{BBH}
\end{aligned}
$$

$\left(\mathrm{R}^{2}=0.959 ; \mathrm{N}=136 ; \mathrm{SE}=87.38\right)$

(Model 5) 
The model for reinforcement quantity in the non-monsoon period is:

$$
\begin{aligned}
\text { Rft non-monsoon }= & -188.669+0.005 \mathrm{H} \\
& +0.052 \mathrm{MD}+0.872 \mathrm{TCH} \\
& +0.391 \mathrm{BCH}-0.339 \mathrm{BBH}
\end{aligned}
$$

$\left(\mathrm{R}^{2}=0.931 ; \mathrm{N}=486 ; \mathrm{SE}=112.54\right) \quad($ Model 6$)$

An examination of the reinforcement models (Models 4, 5 and 6) exhibits a negative sign on the resource of bar bending machine hours, implying that the increase in bar bending hours reduces the quantity of reinforcement. In most cases, reinforcement is provided as straight bars or cut to length. Bending is required in all the bars. Hence, this negative sign implies that, with increase in bar bending instead of being laid straight, there will be a reduction in quantity. On the other hand, Model 6 for reinforcement work in the non-monsoon period shows a positive sign towards the independent variable height. This is due to the use of a higher quantity of long bars on three floors, as a $12 \mathrm{~m}$ bar is useful for floors of $4 \mathrm{~m}$ height in specific cases.

\section{Formwork quantity model}

In this model, formwork quantity is the dependent variable, while the parameters of height $(H)$, man-days $(M D)$, tower crane hours $(T C H)$ and hoist hours $(H H)$ are independent variables.

The best model obtained using multiple linear regression analysis is:

\section{$\mathrm{FW}=-519.279+0.192 H+0.454 M D$$$
+7.223 \mathrm{TCH}+4.856 \mathrm{HH}
$$

$\left(\mathrm{R}^{2}=0.950 ; \mathrm{N}=624 ; \mathrm{SE}=2609.25\right) \quad($ Model 7$)$

The plot between actual quantity (outof-sample data) and the derived quantity (sample data) for formwork validates the model, as shown in Figure 3. The alignment of plotted points along the line of equality indicates the robustness of the model.

The model for formwork quantity in the monsoon period is:

$$
\begin{aligned}
\mathrm{FW} \text { monsoon }= & 41.864+1.828 \mathrm{H}+0.437 \mathrm{MD} \\
& +5.974 \mathrm{TCH}+5.373 \mathrm{HH}
\end{aligned}
$$

$\left(\mathrm{R}^{2}=0.950 ; \mathrm{N}=136 ; \mathrm{SE}=2438.09\right) \quad($ Model 8$)$

The model for formwork quantity in the non-monsoon period is:

$$
\begin{aligned}
\text { FW non-monsoon }= & -313.592-2.609 \mathrm{H} \\
& +0.417 \mathrm{MD}+7.879 \mathrm{TCH} \\
& +4.795 \mathrm{HH}
\end{aligned}
$$

$\left(\mathrm{R}^{2}=0.961 ; \mathrm{N}=51 ; \mathrm{SE}=2056.62\right)$

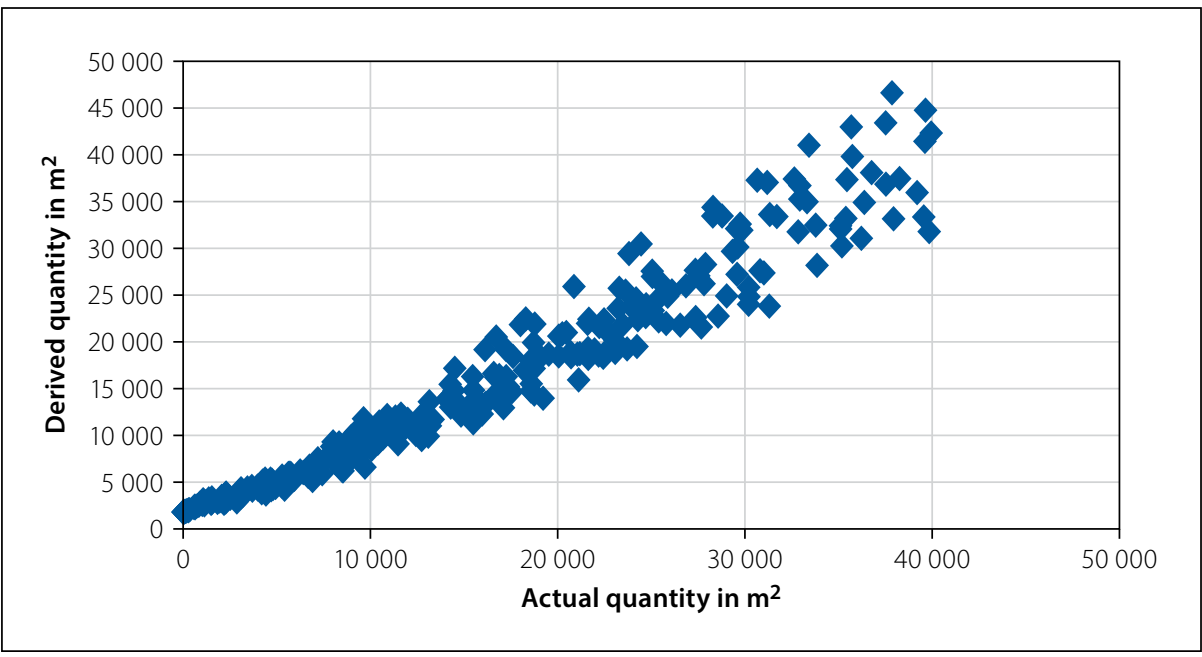

Figure 3 Comparison of actual and predicted quantities for formwork

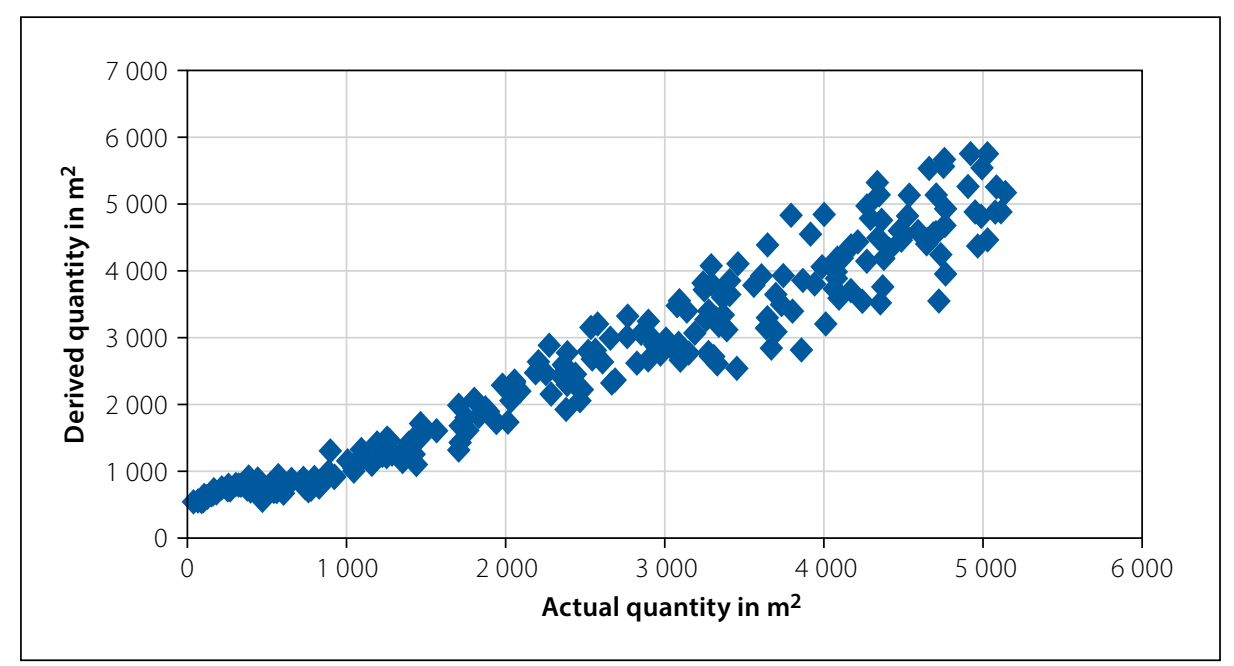

Figure 4 Comparison of actual and predicted quantities for blockwork

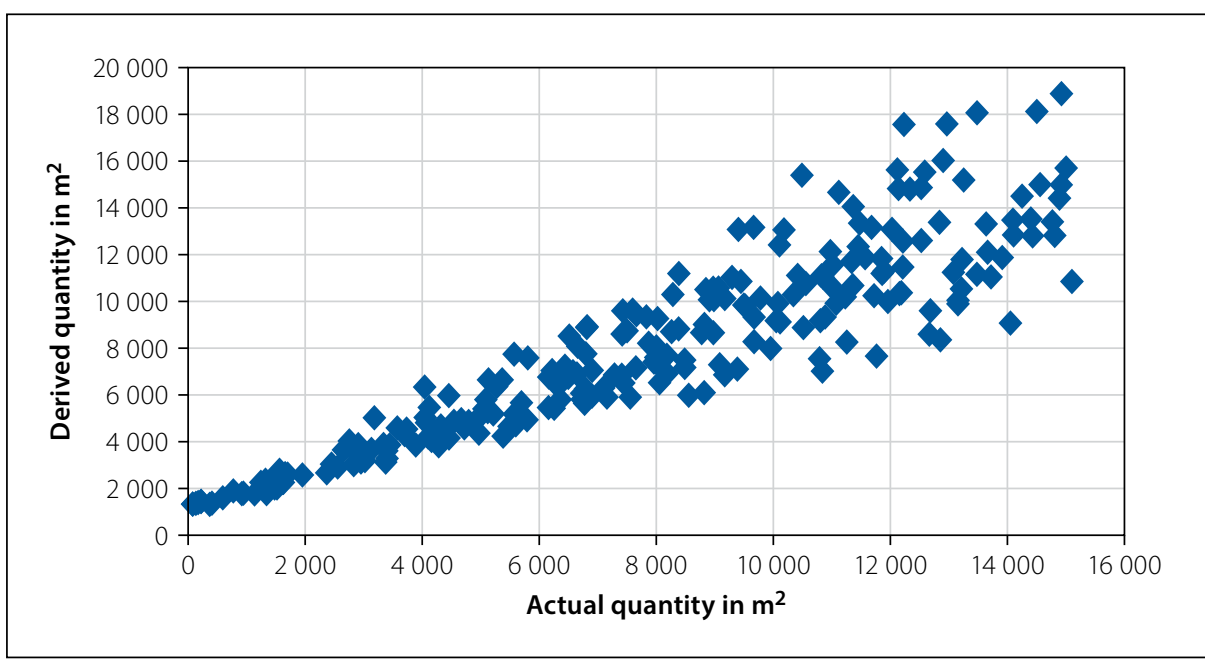

Figure $\mathbf{5}$ Comparison of actual and predicted quantities for plastering

It is observed from the coefficients of the variables in formwork models (Models 8 and 9) that the formwork quantity is higher for the monsoon period than for the non-monsoon period. This may be due to the fact that major quantities of formwork are being done with system formwork and climbing formwork, which involve a continuous process of work, even in the monsoon period but with protection against the rains.

\section{Blockwork quantity model}

In this model, blockwork quantity is the dependent variable, whereas the parameters of height $(H)$, man-days $(M D)$, tower crane hours $(T C H)$, and hoist hours $(H H)$ are independent variables. 


\begin{tabular}{|c|c|c|c|c|c|c|}
\hline S no & Dependent variable & Independent variable & Coefficients & T stat & $P$ value & VIF \\
\hline 1 & \multirow{6}{*}{ Concrete quantity } & $\mathrm{H}$ & -1.249 & 1.990 & 0.046 & \multirow{6}{*}{21.592} \\
\hline 2 & & MD & 0.402 & 9.489 & $4.97 \times 10^{-20}$ & \\
\hline 3 & & $\mathrm{TCH}$ & 0.902 & 8.084 & $3.31 \times 10^{-15}$ & \\
\hline 4 & & $\mathrm{CPH}$ & 1.371 & 5.829 & $8.99 \times 10^{-9}$ & \\
\hline 5 & & $\mathrm{TMH}$ & 2.155 & 11.567 & $3.8 \times 10^{-28}$ & \\
\hline 6 & & $\mathrm{BPH}$ & 5.735 & 18.131 & $3.2 \times 10^{-59}$ & \\
\hline 1 & \multirow{5}{*}{ Reinforcement quantity } & $\mathrm{H}$ & -0.119 & 1.978 & 0.028 & \multirow{5}{*}{14.716} \\
\hline 2 & & MD & 0.047 & 39.446 & $6 \times 10^{-171}$ & \\
\hline 3 & & $\mathrm{TCH}$ & 0.997 & 11.723 & $8.4 \times 10^{-29}$ & \\
\hline 4 & & $\mathrm{BCH}$ & 0.438 & 3.486 & $5.24 \times 10^{-4}$ & \\
\hline 5 & & $\mathrm{BBH}$ & -0.370 & 3.078 & 0.002 & \\
\hline 1 & \multirow{4}{*}{ Formwork quantity } & $\mathrm{H}$ & 0.192 & 2.064 & 0.048 & \multirow{4}{*}{20.153} \\
\hline 2 & & MD & 0.454 & 15.296 & $4.87 \times 10^{-45}$ & \\
\hline 3 & & $\mathrm{TCH}$ & 7.223 & 11.549 & $4.43 \times 10^{-28}$ & \\
\hline 4 & & $\mathrm{HH}$ & 4.856 & 18.017 & $1.16 \times 10^{-58}$ & \\
\hline 1 & \multirow{4}{*}{ Blockwork quantity } & $\mathrm{H}$ & -0.514 & 1.691 & 0.045 & \multirow{4}{*}{14.885} \\
\hline 2 & & MD & 0.183 & 6.792 & $3.3 \times 10^{-11}$ & \\
\hline 3 & & $\mathrm{TCH}$ & 2.887 & 21.123 & $2.53 \times 10^{-70}$ & \\
\hline 4 & & $\mathrm{HH}$ & 1.221 & 18.805 & $2.22 \times 10^{-59}$ & \\
\hline 1 & \multirow{3}{*}{ Plastering quantity } & $\mathrm{H}$ & -0.491 & 2.233 & 0.015 & \multirow{3}{*}{7.206} \\
\hline 2 & & MD & 0.430 & 11.220 & $4.41 \times 10^{-26}$ & \\
\hline 3 & & $\mathrm{HH}$ & 1.863 & 26.174 & $3.24 \times 10^{-94}$ & \\
\hline
\end{tabular}

The best model obtained using multiple linear regression analysis is:

$$
\begin{aligned}
\mathrm{BW}= & 49.662-0.514 \mathrm{H}+0.183 \mathrm{MD} \\
& +2.887 \mathrm{TCH}+1.221 \mathrm{HH}
\end{aligned}
$$

$\left(\mathrm{R}^{2}=0.932 ; \mathrm{N}=480 ; \mathrm{SE}=374.08\right) \quad($ Model 10$)$

The plot between actual quantity (outof-sample data) and the derived quantity (sample data) for blockwork validates the model, as shown in Figure 4. The alignment of plotted points along the line of equality indicates the robustness of the model.

The model for blockwork quantity in the monsoon period is:

$$
\begin{aligned}
\mathrm{BW} \text { monsoon }= & 15.621-1.263 \mathrm{H}+0.176 \mathrm{MD} \\
& +2.529 \mathrm{TCH}+1.404 \mathrm{HH}
\end{aligned}
$$$$
\left(\mathrm{R}^{2}=0.936 ; \mathrm{N}=103 ; \mathrm{SE}=370.76\right) \quad(\text { Model } 11)
$$

The model for blockwork quantity in the non-monsoon period is:

$\mathrm{BW}$ non-monsoon $=-61.466+0.572 \mathrm{H}+$

$$
0.234 \mathrm{MD}+2.753 \mathrm{TCH}
$$

$$
+1.213 \mathrm{HH}
$$

$\left(\mathrm{R}^{2}=0.933 ; \mathrm{N}=376 ; \mathrm{SE}=385.63\right) \quad($ Model 12$)$

\section{Plastering quantity model}

In this model, plastering quantity is the dependent variable, while the parameters of height $(H)$, man-days $(M D)$ and hoist hours $(H H)$ are independent variables.

The best model obtained using multiple linear regression analysis is:

$\mathrm{P}=929.613-0.491 H+0.430 M D+1.863 H H$ $\left(\mathrm{R}^{2}=0.861 ; \mathrm{N}=480 ; \mathrm{SE}=1667.05\right)($ Model 13$)$

The plot between actual quantity (outof-sample data) and the derived quantity (sample data) for plastering validates the model, as shown in Figure 5. The alignment of plotted points along the line of equality indicates the robustness of the model.

The model for plastering quantity in the monsoon period is:

$$
\begin{aligned}
\text { P monsoon }= & 591.723+7.521 H+0.571 M D \\
& +1.607 \mathrm{HH}
\end{aligned}
$$

$\left(\mathrm{R}^{2}=0.865 ; \mathrm{N}=103 ; \mathrm{SE}=1546.55\right)($ Model 14$)$

The model for plastering quantity in the non-monsoon period is:
P non-monsoon $=901.529+1.739 H$

$$
+0.385 \mathrm{MD}+1.881 \mathrm{HH}
$$

$\left(\mathrm{R}^{2}=0.854 ; \mathrm{N}=376 ; \mathrm{SE}=1688.85\right)($ Model 15$)$

\section{Statistical validity of the models}

Table 3 shows the statistical validity of the models and the significance of the variables, verified through validity checks with reference to the standard parameters of " $\mathrm{t}$ " values, "P values" and variance influencing factor (VIF) for each independent variable considered in the models.

The acceptable "student's t" statistic value for $95 \%$ confidence level is 1.645 , but Table 3 reveals "student's t" values of more than 1.645 for all the resource parameters, implying a normal distribution across observations. The acceptable P values is 0.05 but the table shows that "P values" are less than 0.05 , implying that the variables included for model development are significant to the model.

Interestingly, the coefficient of the variable height in each activity, except formwork, is negative, i.e. for activities concrete, reinforcement, blockwork and plastering. The negative value of height 
Table 4 Regression statistics of the developed models

\begin{tabular}{|l|c|c|c|c|c|}
\hline Regression statistics & Concrete & Rft & Formwork & Blockwork & Plastering \\
\hline Multiple R & 0.976 & 0.965 & 0.974 & 0.965 & 0.928 \\
\hline R Ssuare & 0.953 & 0.932 & 0.950 & 0.932 & 0.861 \\
\hline Adjusted R square & 0.953 & 0.931 & 0.950 & 0.932 & 0.860 \\
\hline Standard error & 528.581 & 106.691 & 2609.255 & 374.088 & 1667.056 \\
\hline Observations & 624 & 624 & 624 & 480 & 480 \\
\hline
\end{tabular}

Table 5 ANOVA results of the models

\begin{tabular}{|l|l|l|l|l|l|}
\hline & df & SS & MS & F & Significance F \\
\hline Concrete & & & & \\
\hline Regression & 6 & $3.55 \times 10^{9}$ & $5.92 \times 10^{8}$ & 2117.546 & 0 \\
\hline Residual & 617 & $1.72 \times 10^{8}$ & 279398.4 & & \\
\hline Total & 623 & $3.72 \times 10^{9}$ & & & \\
\hline Reinforcement & & & & \\
\hline Regression & 5 & $9.64 \times 10^{7}$ & $1.92 \times 10^{7}$ & 1695.4 & \\
\hline Residual & 618 & 7034703 & 11383 & & \\
\hline Total & 623 & $1.04 \times 10^{8}$ & & \\
\hline
\end{tabular}

\section{Formwork}

\begin{tabular}{|l|r|l|l|l|l|}
\hline Regression & 4 & $8.07 \times 10^{10}$ & $2.02 \times 10^{10}$ & 2963.957 & 0 \\
\hline Residual & 619 & $4.21 \times 10^{9}$ & 6808210 & \\
\hline Total & 623 & $8.49 \times 10^{10}$ & & \\
\hline
\end{tabular}

\section{Blockwork}

\begin{tabular}{|l|r|r|r|r|r|}
\hline Regression & 4 & $9.23 \times 10^{8}$ & $2.31 \times 10^{8}$ & 1648.934 & $6.5 \times 10^{-277}$ \\
\hline Residual & 475 & 664772660 & 139942 & & \\
\hline Total & 479 & $9.89 \times 10^{8}$ & & \\
\hline
\end{tabular}

\section{Plastering}

\begin{tabular}{l|} 
Regression \\
\hline Residual \\
\hline Total \\
\hline
\end{tabular}

\begin{tabular}{|r|c|}
\hline 3 & $8.21 \times 10^{9}$ \\
\hline 476 & $1.32 \times 10^{9}$ \\
\hline 479 & $9.53 \times 10^{9}$ \\
\hline
\end{tabular}

indicates that, as height increases, productivity decreases. This is logical and understandable, given the increased time for lifting materials from the base for each additional floor. In the four activities the materials have to be lifted from the bottom every time for an additional height, and hence the productivity decreases with increase in height. However, in formwork activity we have a positive coefficient, which defies the above logic. The increase of formwork productivity with height is due to the increased number of repetitions from floor to floor, with the same material being lifted without disturbing the standard configuration. This increase in productivity is attributed to the specialisation that the resources imbibe, due to repetitive nature of the work.

The results of regression statistics and ANOVA for the models are shown in Tables 4 and 5 , respectively.

It is observed from Table 4 that multiple ' $R$ ' is more than 0.9 for all five the models, implying correlation between the observed and predicted value, which is adequate to comply with construction requirements.

The value of significance ' $\mathrm{F}$ ' in Table 5 is less than 0.05 for all five the models, which implies that the developed models are significant. The collinearity statistics for all the independent variables is established indicating that the variance influencing factor (VIF) is greater than ' 1 ' in each case. However, multi-collinearity between the independent variables exists, as the VIF is more than ' 2 '. For example, in concrete work the two independent variables of concrete pump hours and transit mixer hours have strong multi-collinearity because, without a transit mixer to deliver concrete, the concrete pump resource will not be useful.

\section{Inference from quantitative analysis}

In all the above models, the variables such as man hours, tower crane hours, hoist hours and other equipment hours appear

Table 6 Summary of responses - manpower productivity

\begin{tabular}{|c|l|c|c|c|c|c|c|}
\hline S no & Factors & Affects strongly & $\begin{array}{c}\text { Affects } \\
\text { significantly }\end{array}$ & $\begin{array}{c}\text { Affects } \\
\text { moderately }\end{array}$ & Does not affect & Cannot say \\
\hline 1 & Human factors & 34 & 34 & 23 & 3 & 2 \\
\hline 2 & Planning factors & 52 & 30 & 13 & 1 & 0.798 \\
\hline 3 & System factors & 24 & 36 & 27 & 6 & 3 \\
\hline 4 & Environmental factors & 19 & 39 & 31 & 6 & 0.777 \\
\hline
\end{tabular}


Table 7 Summary of responses - equipment productivity

\begin{tabular}{|l|l|c|c|c|c|c|c|}
\hline S No & \multicolumn{1}{|c|}{ Factors } & $\begin{array}{c}\text { Affects } \\
\text { strongly }\end{array}$ & $\begin{array}{c}\text { Affects } \\
\text { significantly }\end{array}$ & $\begin{array}{c}\text { Affects } \\
\text { moderately }\end{array}$ & $\begin{array}{c}\text { Does not } \\
\text { affect }\end{array}$ & Cannot say \\
\hline 1 & Human factors & 30 & 42 & 22 & 2 & 0 \\
\hline 2 & Planning factors & 48 & 32 & 13 & 2 & 1 \\
\hline 3 & System factors & 22 & 41 & 23 & 6 & 2 \\
\hline 4 & Resource/ equipment factors & 27 & 38 & 23 & 6 & 0.808 \\
\hline 5 & Environmental factors & 17 & 37 & 33 & 8 & 2 \\
\hline
\end{tabular}

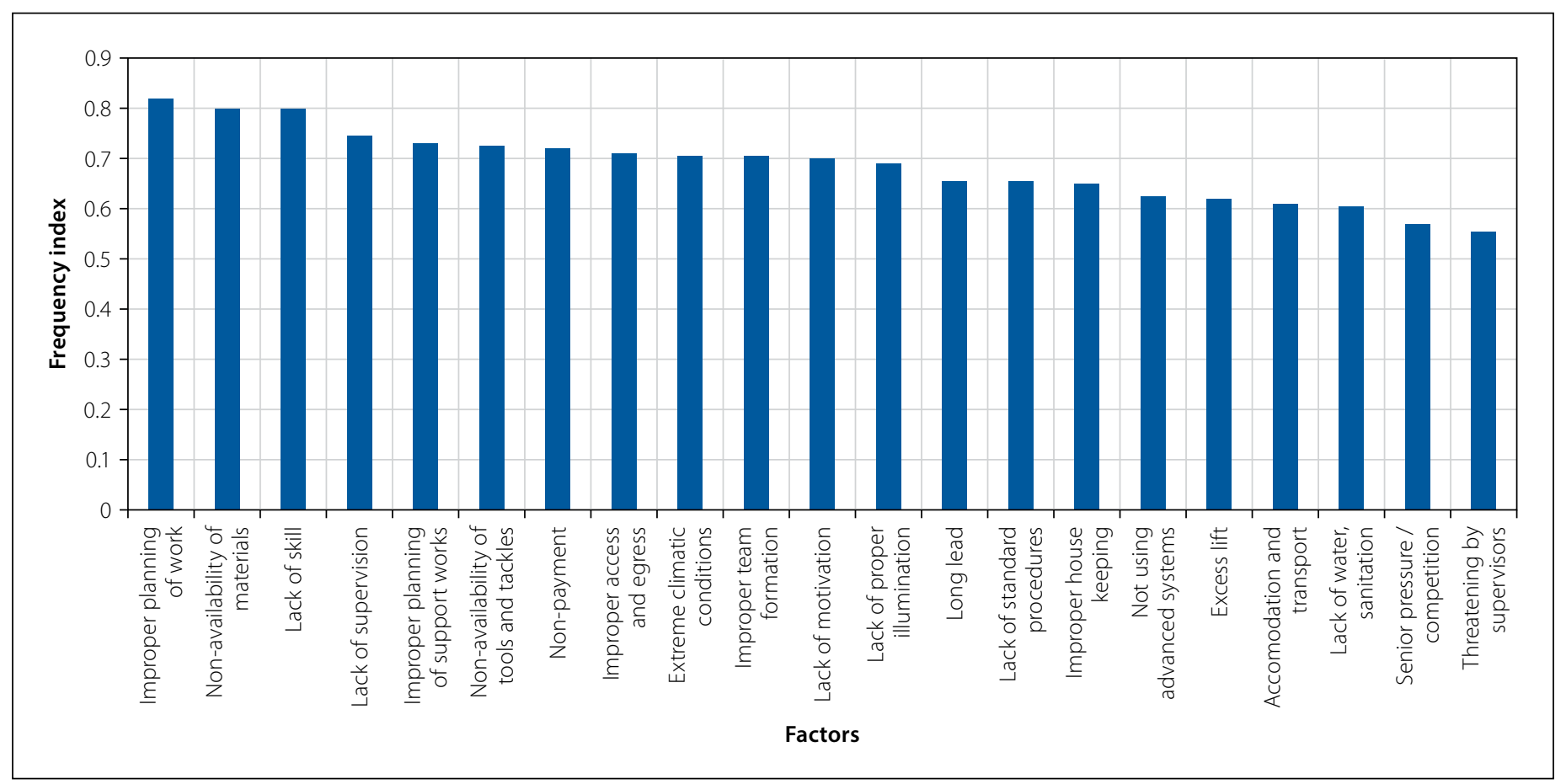

Figure 6 Frequency index for factors affecting manpower productivity

with positive coefficients, indicating that an increase in these variables leads to an increase in productivity. On the other hand, the variable height appears with a negative coefficient, showing that, with the increase in height, the production decreases, except for the formwork model. In all the models the plotted lines aligned along the line of equality, indicating the robustness of the models.

\section{QUALITATIVE ANALYSIS}

\section{Questionnaire responses}

Questionnaires with the factors presented in Table 2 were distributed to 130 persons and responses collected from 96 persons who were involved in the execution of the 52 selected tall residential building projects. The responses were tabulated in order to understand the importance of various factors affecting productivity. The responses to the factors affecting manpower productivity and equipment productivity have been separately analysed and are shown in Tables 6 and 7, respectively.

The relative important index (RII) was calculated for the summary of responses for both manpower and equipment productivity. The RII in Tables 6 and 7 indicates that planning factors are the most important, followed by human factors in both cases.

\section{Frequency indices}

Based on the responses about factors affecting manpower productivity collected from 96 persons, the frequency index for each factor was worked out. The frequency indices for manpower and equipment productivity are depicted in Figures 6 and 7, respectively.

The frequency indices can be used as a measure to ascertain whether the factors considered for this study influence the manpower and equipment productivity. Based on the questionnaire survey and responses in this study, it is observed that 22 out of 41 factors have a frequency index of more than 0.70 , and 38 out of 41 factors have a frequency index of more than 0.60. These indices of 0.70 and 0.60 clearly show that the factors affect productivity and should be taken up for further study.

\section{DISCUSSIONS OF THE FINDINGS}

The quantitative and qualitative studies of the research, based on the data collected from 52 tall residential building construction projects across India and various analyses conducted on them, reveal several findings.

\section{A. Quantitative study}

1. Fifteen multiple linear regression models, three for each of the five basic activities of tall building construction (concreting, reinforcement, formwork, blockwork and plastering) were developed in this study for the productivity of manpower and equipment for tall residential building construction projects covering the monsoon season and the non-monsoon season. 


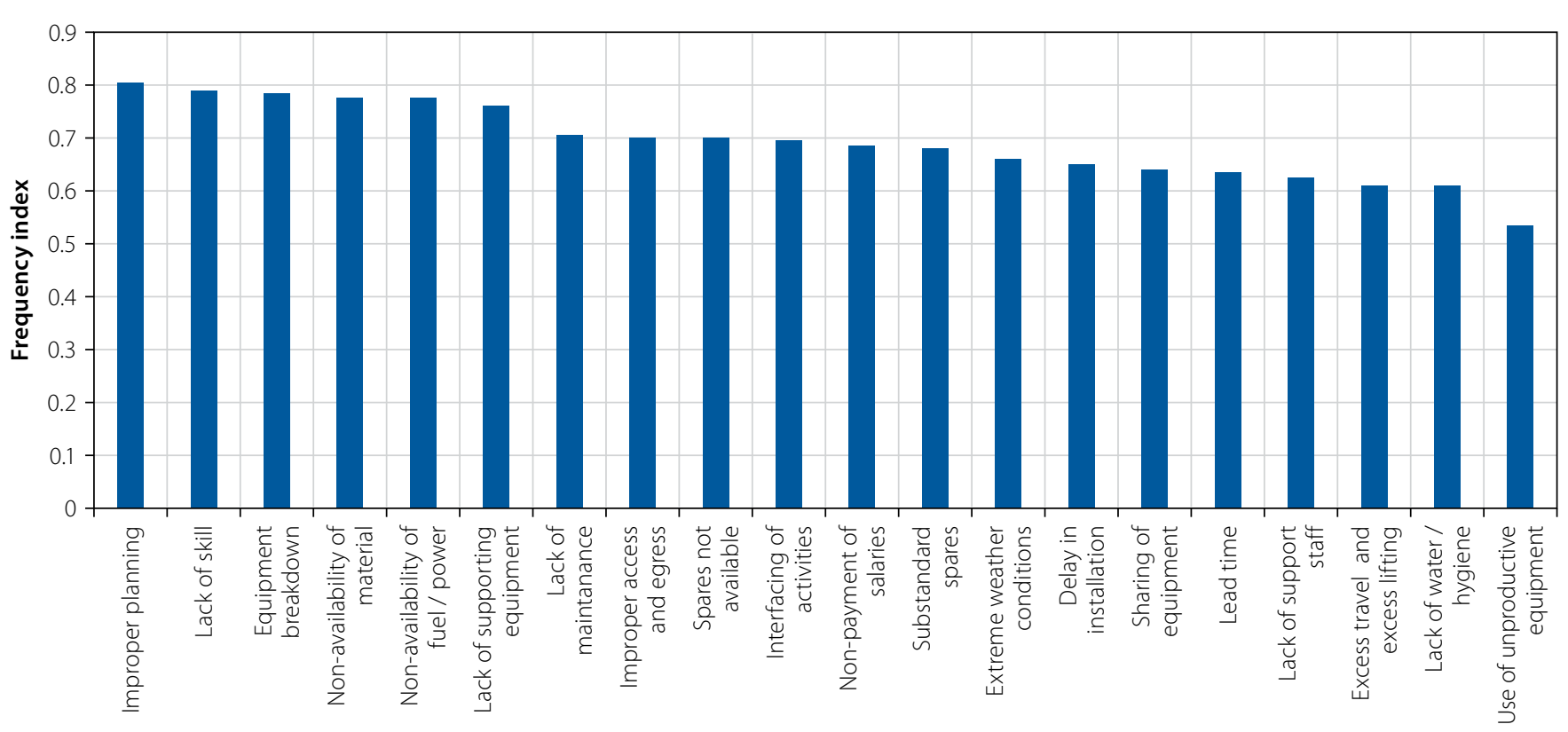

Factors

Figure 7 Frequency index for factors affecting equipment productivity

2. The 15 developed models were evaluated and proven, with reference to the out-of-sample data, and were found to satisfy resource estimation requirements adequately.

3. In all the models, man-days are found to be the most significant explanatory variable influencing the quantity of different activities.

4. Tower crane hours and hoist hours are the next significant explanatory variables influencing the quantities.

5. The effect of monsoon on the quantities of different activities taken for the study is not significant, with a reduction of $2.15 \%$ for concreting quantity, $3.58 \%$ for formwork quantity and $3.90 \%$ for plastering quantity.

6. These models can be used as an effective tool in the estimation and monitoring of manpower and equipment resources in tall building construction projects at different stages of work in India and other South Asian developing countries.

\section{B. Qualitative study}

1. Based on expert opinion, 21 factors affecting manpower productivity were identified and were segregated into four groups: human factors, planning factors, system factors and environmental factors. Twenty factors affecting equipment productivity were identified and were segregated into five groups: human factors, planning factors, system factors, environmental factors and resource/ equipment factors.
2. The frequency indices for the 21 factors affecting manpower productivity, and the 20 factors affecting equipment productivity were calculated from the responses received from 96 respondents to two questionnaires. The range of frequency indices for manpower productivity is between 0.555 and 0.820 , and the range of frequency indices for equipment productivity is between 0.535 and 0.805 .

3. The three important factors affecting manpower productivity are improper planning of work with a frequency index of 0.82 , non-availability of materials with a frequency index of 0.80 , and lack of skill of workman with a frequency index of 0.80 .

4. The three important factors affecting equipment productivity are improper planning of work with a frequency index of 0.81 , lack of skill of operator with a frequency index of 0.79 , and equipment breakdown with a frequency index of 0.78 .

\section{CONCLUSIONS}

Productivity of manpower and equipment resources in construction projects is usually calculated using empirical methods, experience of personnel and in some cases the manufacturer's recommendation. Using models for the estimation and monitoring of productivity provides leverage to the project team to scientifically estimate and monitor productivity for a given set of resources and a given set of conditions in construction projects, particularly tall buildings. In this study, 15 robust models were developed for the five basic activities of construction for three conditions, and these models were validated using outof-sample data. These models cover the resources to be used for each activity in tall building residential projects. Similarly, this study also identifies the factors affecting manpower and equipment productivity, and also the intensity of their effect. The planning factors affect the productivity more than other factors and need to be addressed in construction projects, particularly tall residential building projects.

\section{LIMITATIONS AND SUGGESTIONS FOR FURTHER STUDY}

Firstly, the models developed in this study can be used for tall residential buildings with RCC framed structure of columnbeam-slab construction. However, they cannot be used for the construction of composite structures with structural steel.

Secondly, these models will be useful in construction involving a combination of resource input in the form of manpower and equipment. However, these will not be useful for fully mechanised projects or fully manpower-oriented projects without equipment.

Thirdly, these models can be best applied in South Asian developing countries which follow a certain pattern of construction, with a combination of manpower 
and equipment resources in similar environmental and climatic conditions, especially with similar periods of monsoon and non-monsoon. If the operational and climatic conditions are different, then they may not have much applicability. Further, it is possible to extend the benefit of the models to other construction activities like façade work, interior works, etc, for which the equipment and labour requirement will be different from those of the activities covered in this study.

\section{CONFLICT OF INTEREST}

The authors declare that there is no conflict of interest regarding the publication of this paper.

\section{REFERENCES}

Al-Zwainy, F M S, Abdulmajeed, M H \& Aljumaily, H S M 2013. Using multivariable linear regression technique for modelling productivity construction in Iraq. Open Journal of Civil Engineering, 3(3): 127-135. Antunes, R \& Gonzalez, V 2015. A production model for construction: A theoretical framework. Buildings, 5(1): 209-228.

Attar, A A, Gupta, A K \& Desai, DB 2014. A study of various factors affecting labor productivity and methods to improve it. IOSR Journal of Mechanical and Civil Engineering, 14(1): 11-14.

Chigara, B \& Moyo, T 2014. Factors affecting labor productivity on building projects in Zimbabwe. International Journal of Architecture, Engineering and Construction, 3(1): 57-65.
Dai, J, Goodrum, P M, Maloney, W F \& Srinivasan, C 2009. Latent structures of the factors affecting construction labor productivity. Journal of Construction Engineering and Management, 135(5): 397-406.

Economic Report of the President 2016. Report submitted to the US Congress, February 2016. Available at: http://www.presidency.ucsb.edu/ economic_reports/2016.pdf.

Elbakheit, A R 2012. Why tall buildings? The potential of sustainable technologies in tall buildings. International Journal of High-Rise Buildings, 1(2): 117-123.

Enhassi, A, Mohamed, S, Mustafa, Z A \& Mayer, P E 2007. Factors affecting labor productivity in building projects in the Gaza Strip. Journal of Civil Engineering and Management, 13(4): 245-254.

Gulati, A 2016. Building cities for tomorrow. Available at: http://www.financialexpress.com/economy/ building-cities-for-tomorrow/242301.

Gundecha, M M 2012. Study of factors affecting labor productivity at a building construction project in USA - Web survey. MSc dissertation. Fargo, ND: North Dakota State University.

Gupta, V \& Kansal, R 2014. Improvement of construction labor productivity in Chambal Region. International Journal of Research in Engineering and Technology, 3(10): 34-37.

Jrade, A, Markiz, N \& Albelwi, N 2012. An economical operation analysis optimization model for heavy equipment selection. International Journal of Social, Behavioral, Educational, Economic, Business and Industrial Engineering, 6(1): 146-151.

Mistry, S \& Bhatt, R 2013. Critical factors affecting labor productivity in construction projects: Case study of South Gujarat Region of India.
International Journal of Engineering and Advanced Technology, 2(4): 583-591.

Nguyen, D L \& Nguyen, T H 2013. Relationship between building floor and construction labor productivity. Engineering, Construction and Architectural Management, 20(6): 563-575.

Patil, R 2015. Estimating construction equipment productivity and economics using stochastic methods. International Journal of Research in Engineering, Science and Technologies, 1(8): 341-346. Robles, G, Stifi, A, Jose, L, Ponz-Tienda \& Gentes, S 2014. Labour productivity in the construction industry: Factors influencing the Spanish construction labour productivity. International Journal of Civil, Environmental, Structural, Construction and Architectural Engineering, 8(10): 1061-1070.

Santosh, V \& Apte, M R 2014. Productivity in building construction. IOSR Journal of Mechanical and Civil Engineering, 10(5): 64-71.

Shashank, K, Hazra, S \& Pal, K N 2014. Analysis of key factors affecting the variation of labour productivity in construction projects. International Journal of Emerging Technology and Advanced Engineering, 4(5): 152-160.

Wang, F 2005. On-site labour productivity estimation using neural networks. Available at: http:// spectrum.library.concordia.ca/8516/1/MR10224. pdf (accessed on 13 March 2016).

Zayed, T M \& Halpin, D W 2005. Productivity and cost regression models for pile construction. Journal of Construction Engineering and Management, 131(7): 2-12. 